\title{
C. P. E. Bach's "Art" and "Craft"? Galant Schemata and the Rule of the Octave as Markers of Convention in Selected Keyboard Sonatas and in the Versuch
}

Gilad Rabinovitch / grabinovitch@gsu.edu

School of Music, Georgia State University, USA

\begin{abstract}
One of the central issues in the discourse on C. P. E. Bach's music is the relation between the public and private aspects of his work. Recent scholarship on partimenti and galant schemata (Gjerdingen 2007, Sanguinetti 2012) proposes a new view of the craft of eighteenth-century composition: it suggests that composers relied on a limited number of commonplace patterns, in contrast with later notions of the artwork as a uniquely inspired creation. This paper examines case studies from C. P. E. Bach's keyboard sonatas in which galant schemata might serve as markers of conventional "craft" and individualised "artistic" expression. I also comment briefly on Bach's sophisticated manipulations of the conventional Rule of the Octave in his Versuch (1753/1762).
\end{abstract}

\section{Keywords}

C. P. E. Bach, Gjerdingen, schema theory, eighteenth-century music, galant style, Rule of the Octave 
I would like to start this talk with two quotations on eighteenth-century music:

“[In Haydn's and Mozart's works] we witness an endless ebb and flow of ideas, an unending eloquence, and unending melody. The guiding principle is not symmetry, not the formation of periods, not the desire for an even number of measures, not 'strong and weak,' not the fashioning of so-called themes - their freedom is not bound by any one of these. There is no trace of mechanistic falsehood; instead one is everywhere happily surprised by newly created ideas. ... But surely genius knows no limitation. The music of these minds speaks as with words. Just as the speech of man is untrammeled and is governed only by the matter at hand, so the music of these geniuses is unconfined, and is but lightly chained to the eternal laws of nature."

SCHENKER, Heinrich. Ein Beitrag zur Ornamentik. Vienna: Universal, 1904/1907. Trans. Hedi Siegel, A Contribution to the Study of Ornamentation, Music Forum 1976, vol. 4, p. 34.

"[I]f one adopts the perspective of twenty-first-century ethnomusicology, eighteenth-century galant musicians in Naples, Dresden, Versailles, or London do not look so very different from eighteenth-century court musicians in Tehran, Delhi, Yogyakarta, or Seoul. All these artisans worked in preindustrial cultures where highly trained, often hereditary musicians catered to the refined tastes of noble patrons. Training in any of these traditions took years and required the memorization of huge amounts of musical vocabulary and repertory. Apprentices learned how traditional melodic figures and motifs could be fit within frameworks of scales and meters, and which music should be chosen for various moods, occasions, and ceremonies. In styles that favored improvisation, young musicians practiced how to select strings of patterns that helped to fashion larger formal or narrative designs..."

GJERDINGEN, Robert O. Music in the Galant Style. NY: Oxford University Press, 2007, p. 370.

\begin{tabular}{|l|l|}
\hline Schenker & Gjerdingen \\
\hline The Masterwork in Music, uniqueness & the psychology of convention, typicality \\
\hline $\begin{array}{l}\text { One prototype (Ursatz - 3 variants), } \\
\text { principles of counterpoint operate on } \\
\text { multiple levels in a piece }\end{array}$ & $\begin{array}{l}\text { More than } 20 \text { local, near-surface prototypes, } \\
\text { variants, and clausulae, elaborated on the } \\
\text { musical surface }\end{array}$ \\
\hline $\begin{array}{l}12 \text { "Great" composers, mostly German- } \\
\text { speaking, ca. 1700-1900 }\end{array}$ & $\begin{array}{l}\text { Both forgotten and canonic composers, } \\
\text { Neapolitan training methods, the } \\
\text { dissemination of the related galant style } \\
\text { across Europe, ca. 1720-1780 }\end{array}$ \\
\hline Music as art & Music as craft \\
\hline
\end{tabular}

Tab. 1 Comparing Some Aspects of Schenker's and Gjerdingen's Work

My intention in juxtaposing these two excerpts from Heinrich Schenker and Robert Gjerdingen was not so much to make Schenker into a scapegoat, but rather to highlight 
some of the cultural attitudes surrounding European art music, which might still characterise some present-day thinking. In addition, I wanted to contrast Gjerdingen's somewhat new work on galant schemata with what might be a more familiar body of theoretical literature to the conference attendees - though, of course, one to which the Meyer-Narmour-Gjerdingen scholarly lineage is antithetical (see Tab. 1). Coincidentally, Schenker's essay emphasises the central influence of C. P. E. Bach on the high-classical masters; Gjerdingen's work emphasises the importance of the mid-eighteenth-century galant style for understanding the works of Haydn and Mozart, among many others. The contrast between the theoretical work of the two scholars is considerable: Schenker ultimately proposed the Ursatz prototype, a large-scale skeleton that is elaborated contrapuntally on multiple levels by unique master composers, mostly German speaking; Gjerdingen describes more than twenty commonplace skeletons or cognitive schemata, which are combined in succession and elaborated on the musical surface. Gjerdingen draws on the Neapolitan pedagogical tradition of partimenti, as well as on the works of the many forgotten eighteenth-century composers, revealing a normative grammar for musicians and listeners. Of course, the contrast between music as "art" and music as "craft" in the two quotations is most evident.

Many pieces on the early side of the extended galant style (1720-1780) open with a combination of the Romanesca and Prinner schemata-described in Gjerdingen's Chapters 2 and 3-and characterised by a soprano and bass skeleton that may manifest itself as follows:

ROMANESCA $\rightarrow$

PRINNER

\begin{tabular}{|l|l|l|l|l|l|l|c|c|}
\hline Soprano Scale Degrees & 1 & 5 & 8 & 5 & 6 & 5 & 4 & 3 \\
\hline Bass Scale Degrees & 8 & 7 & 6 & 3 & 4 & 3 & $2-5$ & 1 \\
\hline
\end{tabular}

Ex. 1 A skeletal combination of galant Romanesca and Prinner, after GJERDINGEN, Robert O. Music in the Galant Style.

NY: Oxford University Press, 2007 (see, e.g., examples on pp. 48-50)

C. P. E Bach's music is a particularly interesting case study for the tension between musical art and craft: many of his pieces were intended for a large audience of amateurs or for public performances, whereas other pieces were conceived as a more personal artistic expression. ${ }^{1}$ Moreover, despite Bach's reservations about the comic style represented by one of the galant operatic masters, Baldassare Galuppi, ${ }^{2}$ Bach's music is typically galant: many of his pieces - both "public" pieces and "personal" ones - can be explained using the schemata proposed in Gjerdingen's book Music in the Galant Style.

1 As C. P. E. Bach attested to Charles Burney, most of his pieces were written with the taste of others in mind and only a minority of them were written for himself. This account is cited in KRAMER, Richard. Unfinished Music. NY: Oxford University Press, 2008, p. 33.

2 See SCHULENBERG, David. The Music of Carl Philipp Emanuel Bach. Rochester, NY: University of Rochester Press, 2014, p. 194. 
In fact, many of C. P. E. Bach's pieces are a succession of schema by schema from Gjerdingen's set of patterns.

Since Gjerdingen's work describes commonplace schemata, one might ask the following question: can galant schemata help us to outline the tension between conventional "craft" and idiosyncratic "artistic" expression in the works of C. P. E. Bach? To what extent do some of his more personal pieces deviate from these patterns? This question is quite similar to the one posed by Olga Sánchez-Kisielewska in her work on the Italian influence on the mass settings of Ignacio Jerusalem and José de Nebra. ${ }^{3}$ She uses Gjerdingen's prototypes as markers for the degree of spread of the Italian galant style to the two Spanish-speaking composers, who were active in Mexico and Madrid, respectively. Gjerdingen's schemata thus highlight the influence of the galant style on the periphery of European church music. This allows the discussion of style history to become concrete rather than vague. ${ }^{4}$

C. P. E. Bach's attempts at personal artistic expression also emerge at a critical cultural juncture, when romantic notions of the artwork and the artist began to develop. ${ }^{5}$ However, the degree of conformance of Bach's more "personal" compositions to conventional patterns sheds some ambiguous light on this issue.

The following musical examples react to parts of the analytical commentary in Richard Kramer's book Unfinished Music. I would like to revisit some passages discussed by this prominent scholar in order to show the specific potential contribution of Gjerdingen's schemata to our understanding of this music. Bach's use of schemata in these examples is quite representative of pieces closer to the difficult and personal pole of his output, yet my discussion will suggest that they have many conventional aspects. Kramer refers to the sonata H. 248, composed in 1775, as a piece that "displays that inimitable originality that had come to be prized as a defining attribute of genius." ${ }^{6}$ While this sonata certainly displays many striking features, uncovering underlying schemata shows that it is also typically galant. The opening bars 1-2 (Ex. 2) are a play on Gjerdingen's galant Romanesca (see Ex. 1).

3 SÁNCHEZ-KISIELEWSKA, Olga. Claves para el Análisis del Italianismo en la Música Hispana: Esquemas Galantes y Figuras Retóricas en las Misas de Jerusalem y Nebra. Diagonal: An Ibero-American Music Review 2015 vol. 1, no. 1, p. 28-53.

4 The two massive corpus studies by Gjerdingen and Byros show in a quantifiable way the rise and fall in prevalence of two specific patterns, which peak in the 1770 s and 1790 s, respectively. See GJERDINGEN, Robert O. A Classic Turn of Phrase: Music and the Psychology of Convention. Philadelphia: University of Pennsylvania Press, 1988; BYROS, Vasili. Foundations of Tonality as Situated Cognition, 1730-1830: An Enquiry into the Culture and Cognition of Eighteenth-Century Tonality with Beethoven's 'Eroica' Symphony as a Case Study. PhD Dissertation: Yale University, 2009. For Gjerdingen's brief references to the usage of conventional, artisanal (rather than "artistic") schemata in C. P. E. Bach's works and treatise, see GJERDINGEN, Robert O. Music in the Galant Style. NY: Oxford University Press, 2007, p. 99-100, 183-184, 399.

5 For instance, see KRAMER, op. cit., p. 27.

6 KRAMER, op. cit., p. 33-34. 


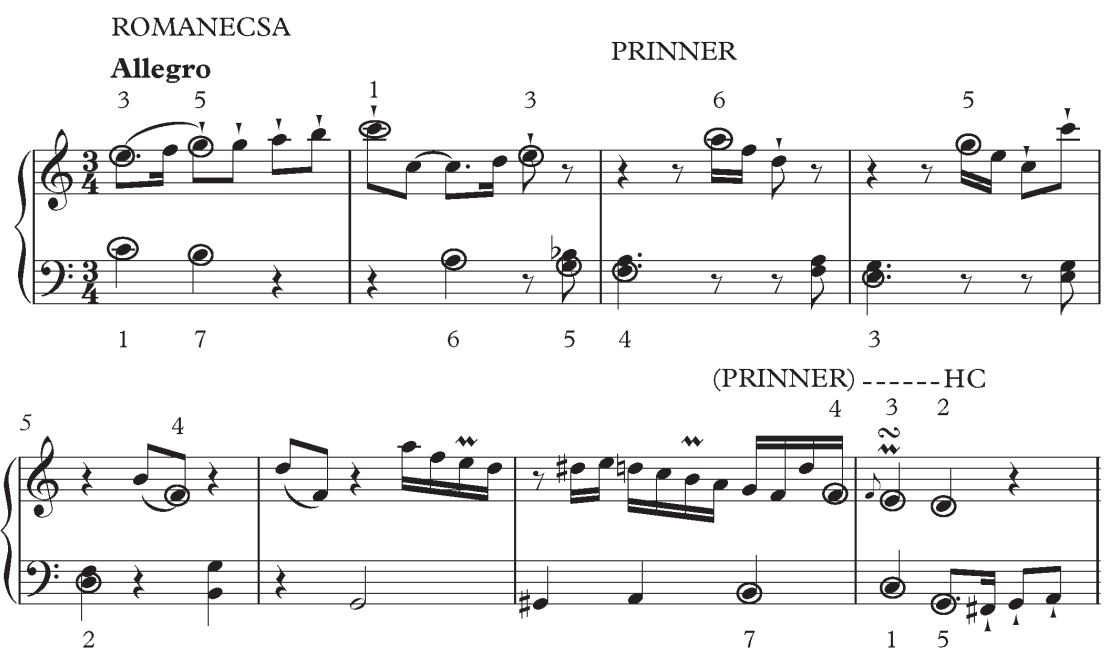

Ex. 2 C. P. E. Bach, Keyboard Sonata H. 248, first movement, bars 1-8.

The answer to the Romanesca is the conventional Prinner, which Bach manipulates in the next few measures of the sonata: while the first two stages of the Prinner schema are realised in a relatively conventional manner in bars $3-4$, the last two schema events are considerably elaborated by the hesitant gestures of bars 5-6 and by the flourish of bars 6-7. The comparison between Examples 1 and 2 is striking: conventional patterns are both retained and transformed in Bach's piece, creating a somewhat unusual musical surface.

Kramer refers to the phrase first presented in bars 33-37 of the development as "the most overtly coherent phrase in the piece (the only coherent one, by some measure)."7
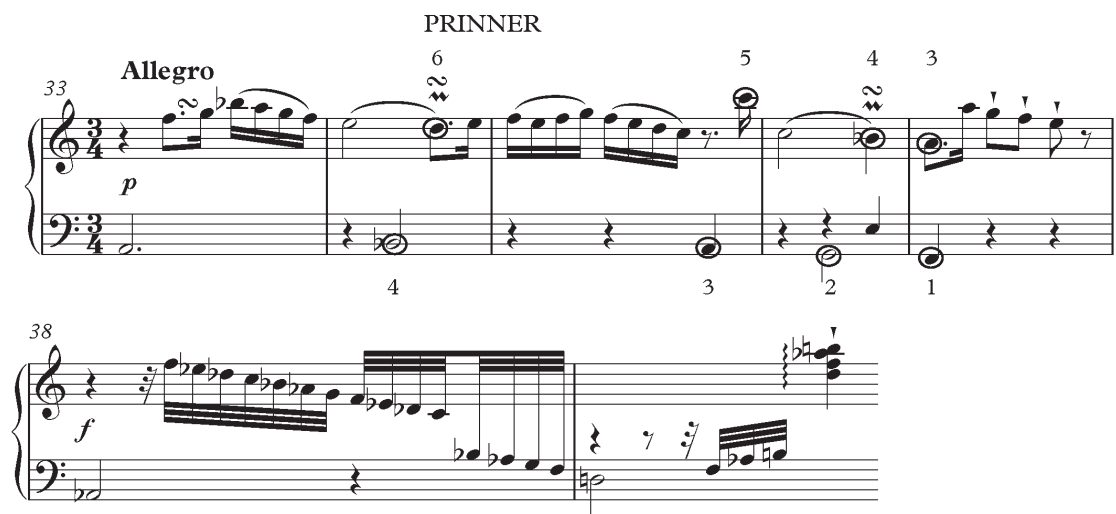

Ex. 3 C. P. E. Bach, Keyboard Sonata H. 248, first movement, bars 33-39. 
Indeed, this is yet another commonplace Prinner, which, as Kramer observes, is abruptly abandoned. It is quite conceivable that Kramer's intuition that this is a "coherent" phrase is influenced by the underlying stock pattern. Unlike the Prinner near the opening of the movement, this one projects all the core tones of the skeleton in a somewhat more regular way before it dissolves.

The sonata H. 243 (Ex. 5) starts off-tonic and, moreover, with a gesture atypical of a beginning of a piece. Kramer points out the unusual tonal and rhetoric aspect of this sonata. ${ }^{8}$ This opening gesture is in fact the Monte schema, one of the schemata that Gjerdingen derived from the mid-century theoretical writings of Joseph Riepel. Riepel (see Ex. 4) refers to this pattern as Schusterfleck, that is, "cobbler's patch": as the example and brief text excerpt reproduced from Riepel's treatise shows, he thought of it as useful for beginners. The well-known artisanal metaphor goes along with the theme of this conference and with the present considerations.

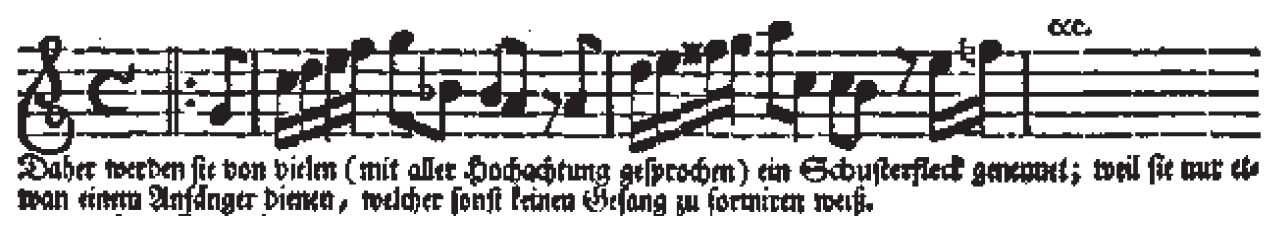

\section{Ex. 4 J. Riepel's (and Gjerdingen's) Monte pattern, from RIEPEL, Joseph. Anfangsgründe zur musicalischen Setzkunst (1. Band - De Rhythmopoeïa oder von der Tactordnung).}

Regensburg: Bader, 1752, p. 19.

The example from Riepel situates the Monte in a typical location, just after the middle double bar of a two-reprise form. The Monte is often found in other "middle" positions of eighteenth-century musical form, which makes the beginning of Bach's piece unusual, in medias res. Moreover, both stages of Bach's Monte have a minor modal quality rather than the typical major quality.

Despite this unusual beginning, which leads to an Indugio-schema based half cadence in bar 4, the rest of Bach's first half displays a typical succession of Gjerdingen's schemata and the conventional script in which they are deployed in eighteenth-century musical form. ${ }^{9}$ The Pastorella of bars 5-6 - one of Meyer's original "changing-note schemata," is an appropriate opener for a phrase or even a movement; the Monte of bar 7 is appropriately situated in the middle of the phrase, and coincides with what William Caplin terms the "fragmentation" within a sentence, which occurs typically after a doubly-presented

\footnotetext{
8 KRAMER, op. cit., 80-81.

9 I use the term "script" based on the following sources: BYROS, Vasili. "Hauptruhepuncte des Geistes": Punctuation Schemas and the Late-Eighteenth-Century Sonata. In What is a Cadence?: Theoretical and Analytical Perspectives on Cadences in the Classical Repertoire. Markus Neuwirth - Pieter Bergé (eds). Leuven: Leuven University Press, 2015, p. 215-251; GJERDINGEN, Robert O. A Classic Turn of Phrase: Music and the Psychology of Convention. Philadelphia: University of Pennsylvania Press, 1988; MEYER, Leonard B. Style and Music: Theory, History, and Ideology. Chicago: University of Chicago Press, 1989. SCHANK, Roger - ABELSON, Robert. Scripts, Plans, Goals, and Understanding: An Inquiry into Homan Knowledge Structures. New York: Halsted, 1977.
} 

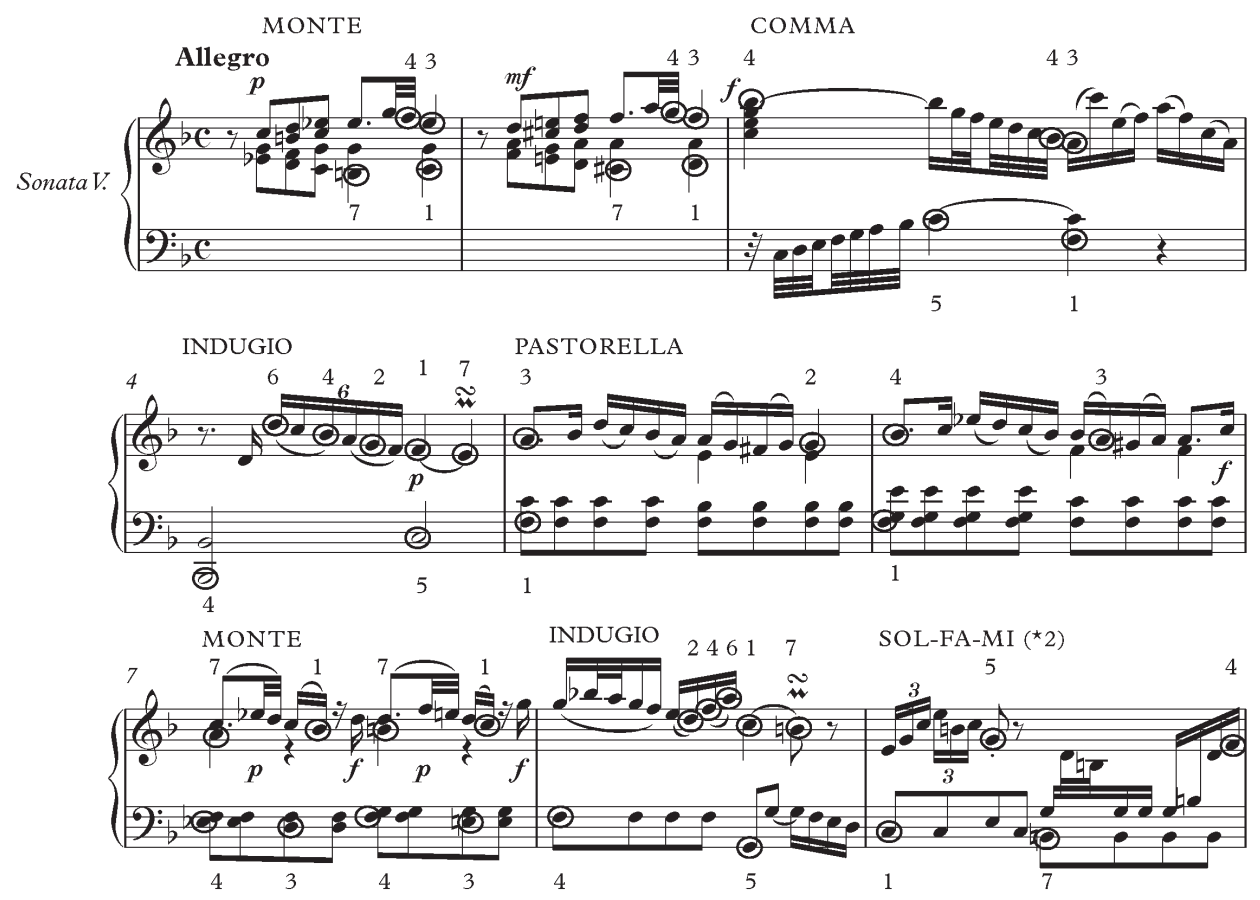

GRAND CADENCE...

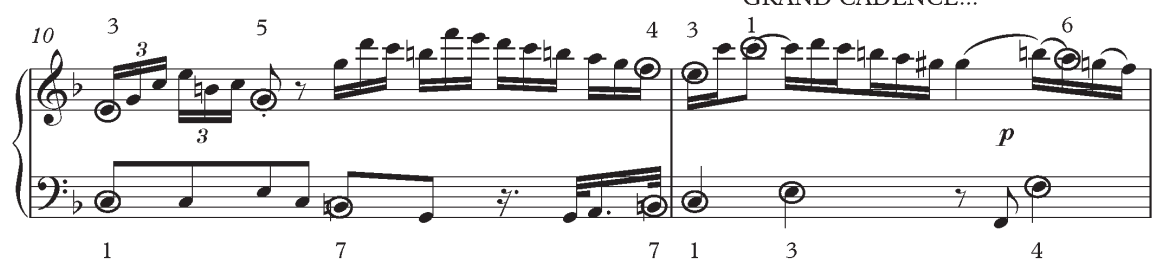

... (DECEPTIVE) GRAND CADENCE (COMPLETE)

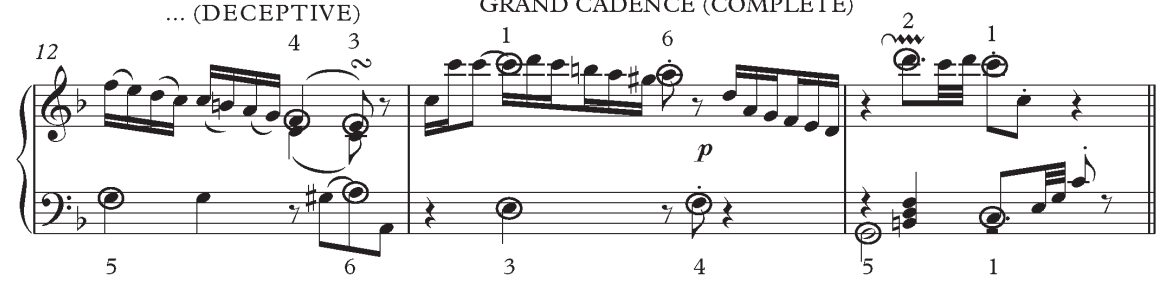

Ex. 5 C. P. E. Bach, Keyboard Sonata H. 243, first movement, bars 1-14. 
basic melodic idea (here, the two halves of the Pastorella schema). ${ }^{10}$ The ensuing Indugio schema of bar 8 carries the cadential formal function of this orderly phrase.

The secondary key area materials (bars 9-14) consist of a brief, twice-repeated SolFa-Mi prototype (in Gjerdingen's terms), and a typically galant bass pattern of Deceptive Cadence - Complete Cadence, or scale degrees $\wedge 3-\wedge 4-\wedge 5-\wedge 6$ followed by $\wedge$ 3-^4-^ $5-\wedge 1$, a standard way of delaying the final cadence of a section in the style, matched with Gjerdingen's Grand Cadence soprano pattern. A brief excerpt from the aria Quae moerebat et dolebat (Ex. 6) of Pergolesi's Stabat mater, which contains the Deceptive... Complete Cadence succession, will serve as yet another illustration of the way in which Bach's ornate surface relies on basic idiomatic patterns.

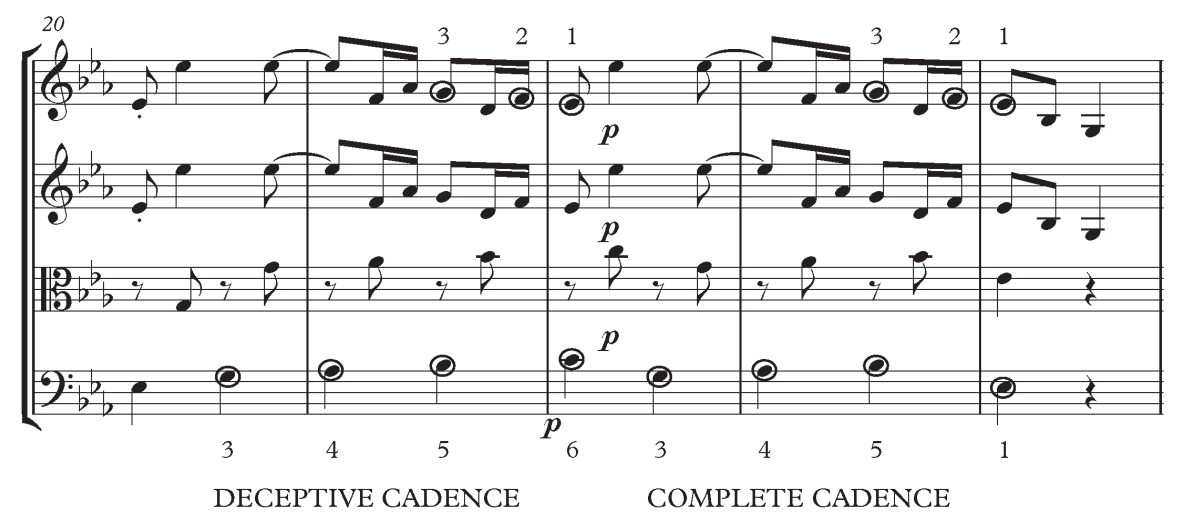

Ex. 6 G. B. Pergolesi, Quae moerebat et dolebat from Stabat Mater, bars 20-24.

Thus, while galant schemata help to define some of the unusual features of the beginning of this section, it proceeds with a normative succession of galant skeletons. Once again, Gjerdingen's schemata help us to unravel typical and atypical aspects of this music. Despite the aura of individual artistic expression that surrounds Bach's figure, some of his more idiosyncratic pieces draw on galant norms, even if they are manipulated in unusual ways.

I would like to end with a very brief discussion of C. P. E. Bach's treatment of the Rule of the Octave in the chapter on improvisation that concludes the second part of his Essay on the True Manner of Playing Keyboard Instruments. ${ }^{11}$ Bach seems to have had reservations about the Rule of the Octave-he refers to it as a useful model for even modestly skilled players. ${ }^{12}$ Besides the conventional harmonisation for ascending and descending

10 CAPLIN, William E. Classical Form: A Theory of Formal Functions for the Instrumental Music of Haydn, Mozart, and Beethoven. NY: Oxford University Press, 1998.

11 BACH, Carl Philipp Emanuel, Versuch über die wahre Art das Clavier zu spielen. Berlin: Henning / Winter, 1753, 1762. For a complete reference to Mitchell's translation, which renders Art in the original title as "Art," see the bibliography.

12 BACH, op. cit., 327-328. See also William Mitchell's comment on p. 431-432, fn. 3 of his translation of the treatise regarding Bach's dismissive treatment of the Rule, which he does not mention explicitly. 
bass scales, Bach includes versions enriched with chromaticism as well as re-orderings of segments of the Rule of the Octave. Bach's dismissive comment, his variant harmonisations, and his re-orderings of segments of the Rule of the Octave, all suggest that he was not sanguine about this model, which was a ubiquitous keyboard exercise in both Neapolitan partimenti and in figured-bass treatises. ${ }^{13}$ Moreover, as Sanguinetti, Christensen, and others have observed, the possibility of segmenting the Rule of the Octave into shorter scalar patterns, some transposed to different tonal centres, was also conventional. ${ }^{14}$ Moving from production to analysis and cognition, the Rule of the Octave allowed to conceptualise musical passages as segments of different transpositions of the Rule. ${ }^{15}$ Such patterns and procedures were part and parcel of the training of eighteenth-century musicians - In Naples and elsewhere - and reflected the grammar shared by musicians and their noble and bourgeois listeners. ${ }^{16}$ Thus, even some of Bach's radical re-orderings of the Rule of the Octave may be conceptualised or perceived as shifting to a different scalar template of the Rule of the Octave, as in the annotated Example 8, which may be compared to the conventional Example 7. This suggests that Bach's sophisticated manipulations of the Rule can be partially construed along normative lines.

\begin{tabular}{|l|c|c|c|c|c|c|c|c|}
\hline Figured-bass sonorities & 3 & 3 & 8 & 6 & 5 & 6 & 5 & 3 \\
& 8 & $\# 6$ & 6 & 5 & 3 & 3 & 3 & 8 \\
& 5 & 4 & 3 & 3 & 8 & & 6 & 5 \\
\hline $\begin{array}{l}\text { Bass scale-degrees } \\
\text { (ascending) }\end{array}$ & 1 & 2 & 3 & 4 & 5 & 6 & 7 & 8 \\
\hline
\end{tabular}

\begin{tabular}{|l|c|c|c|c|c|c|c|c|}
\hline Figured-bass sonorities & 3 & 6 & 4 & 5 & 6 & 8 & 3 & 3 \\
& 5 & 3 & 3 & 3 & $\# 4$ & 6 & 6 & 8 \\
& 8 & & $\# 6$ & 8 & 2 & 3 & 4 & 5 \\
\hline $\begin{array}{l}\text { Bass scale-degrees } \\
\text { (ascending) }\end{array}$ & 8 & 7 & 6 & 5 & 4 & 3 & 2 & 1 \\
\hline
\end{tabular}

Ex. 7 A Typical Rule of the Octave, after SANGUINETTI, Giorgio. The Art of Partimento: History, Theory, and Practice. NY: Oxford University Press, 2012, p. 121.

13 For two of the many sources dealing extensively with the Rule of the Octave, see: CHRISTENSEN, Thomas, The 'Règle de l'octave' in Thorough-Bass Theory and Practice," Acta Musicologica 1992, vol. 64, p. 91-117; SANGUINETTI, Giorgio. The Art of Partimento: History, Theory, and Practice. NY: Oxford University Press, 2012, Chapter 9.

14 As Sangunetti writes, "one of the great advantages of the [Rule of the Octave] is that it can be used even for short segments, provided one is able to locate them correctly within the appropriate scale." SANGUINETTI, op. cit., p. 114-115.

15 For instance, Joel Lester discusses an anonymous analysis from the J. S. Bach circle of Well-Tempered Clavier preludes in terms of local segments of the Rule. See LESTER, Joel. Compositional Theory in the Eighteenth Century. Cambridge: Harvard University Press, 1992, p. 82 ff.

16 The question of musical communication and the challenges of finding audiences for contemporary art music were a recurring theme in our dialogues at this conference. 


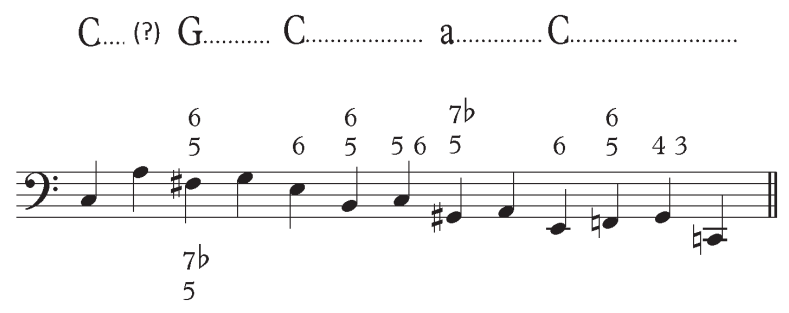

Ex. 8 Annotated Re-Ordering of segments from the Rule of the Octave, after $\mathrm{BACH}$, Carl Philipp Emanuel, Versuch über die wahre Art das Clavier zu spielen. Berlin: Henning / Winter, 1753, 1762, p. 329.

The annotated segments are taken from the Rule of the Octave, transposed to various tonal centres: uppercase letters signify a major tonality, lowercase signifies minor. One may observe that there are fairly slight harmonic variants and embellishments compared to the commonplace model of Ex. 7. For instance, the final C-major segment, E-F-G-C, represents the segment $\wedge 3-\wedge 4-\wedge 5$ from the ascending Rule of the Octave with an added suspension, followed by the typical $5 / 3$ sonority on the tonic.

I mentioned that transposing the Rule of the Octave to different tonal centres was conventional. Late on in the chapter, Bach states that the leading tone or semitonium modi may determine the local sense of key - this can help the improviser to manipulate listeners' expectations in the fantasia. He writes further:

"Es ist bey dem Fantasieren eine Schönheit, wenn man sich stellet, durch eine förmliche Schlußcadenz in eine andere Tonart auszuweichen, und hernach eine andere Wendung nimmt. Diese, und andere vernünftige Betrügereyen Machen eine Fantasie gut: allein sie müssen nicht immer vorkommen, damit das Natürliche nicht ganz und gar darbey verstecket werde."17

"It is one of the beauties of improvisation to feign modulation to a new key through a formal cadence and then move off in another direction. This and other rational deceptions make a fantasia attractive; but they must not be excessively used, or natural relationships will become hopelessly buried beneath them." (Mitchell's translation, p. 434)

Eighteenth-century musicians and listeners seem to have had a localised sense of key, in contrast with modern-day notions of overarching monotonality. ${ }^{18}$ The Rule of the Octave and the ability to segment and transpose it was one important way in which

17 BACH, op. cit., p. 330.

18 See the particularly elegant treatment of this problem in BYROS, Vasili. Foundations of Tonality as Situated Cognition, 1730-1830: An Enquiry into the Culture and Cognition of Eighteenth-Century Tonality with Beethoven's 'Eroica' Symphony as a Case Study. PhD Dissertation: Yale University, 2009. In his treatise chapter under consideration here, Bach makes additional comments on listeners' expectations in relation to tonal factors such as the establishment of the home key and modulation schemes. Such issues must remain outside the scope of this brief talk. 
eighteenth-century musicians conceptualised tonal motion. Bach's discussion here clarifies that he was not only interested in sophisticated and artful manipulations of conventional models, but also in musical communication. Even though Bach belonged to a small club of elite expert or master composers ${ }^{19}$ - who surely had knowledge inaccessible even to enculturated listeners who were closer to the Kenner side of listening expertise - his comments regarding manipulating listeners' expectations stress that he was explicitly interested in shared aspects of musical communication.

This preliminary inquiry has shown some of the tensions between convention and individual expression in the music and writings of C. P. E. Bach, providing an eighteenth-century case study for the theme of this conference - the relation between music as "art" and as a professional "craft." I intend to expand this line of work in the future in two ways: 1) Revisiting the issue of Bach and improvisation based on Gjerdingen's schemata, the Versuch, and improvisatory pieces such as the Sonatas with Varied Reprises; 2) Extending the analytical work on commonplace schemata and idiosyncratic expression in Bach's keyboard works. This future work will shed further light on the art and craft of this master composer.

\section{Bibliography}

BACH, Carl Philipp Emanuel, Versuch über die wahre Art das Clavier zu spielen. Berlin: Henning / Winter, 1753, 1762. Trans. William J. Mitchell. Essay on the True Art of Playing Keyboard Instruments. New York: W. W. Norton \& Company, 1949.

BROWN, Matthew. Explaining Tonality: Schenkerian Theory and Beyond. Rochester, NY: University of Rochester Press, 2005.

BROWN, Matthew. CPE Bach, Schenker, Improvisation, and Composition, Intégral 2010, vol. 24, p. 3-27.

BYROS, Vasili. Foundations of Tonality as Situated Cognition, 1730-1830: An Enquiry into the Culture and Cognition of Eighteenth-Century Tonality with Beethoven's 'Eroica' Sympnony as a Case Study. PhD Dissertation: Yale University, 2009.

BYROS, Vasili. "Hauptruhepuncte des Geistes": Punctuation Schemas and the Late-EighteenthCentury Sonata. In What is a Cadence?: Theoretical and Analytical Perspectives on Cadences in the Classical Repertoire. Markus Neuwirth - Pieter Bergé (eds). Leuven: Leuven University Press, 2015, p. 215-251.

19 In his recasting of Schenkerian theory, Matthew Brown stresses the role of (elite) cognitive expertise in the training and works of the master composers cherished by Schenker. See BROWN, Matthew. Explaining Tonality: Schenkerian Theory and Beyond. Rochester, NY: University of Rochester Press, 2005. Cf. also BROWN, Matthew. CPE Bach, Schenker, Improvisation, and Composition. Intégral 2010, vol. 24, p. 3-27, which comments on SCHENKER, Heinrich. Die Kunst der Improvisation, in Das Meisterwerk in der Musik 1. Munich: Drei Masken Verlag, 1925, p. 11-40. Trans. Richard Kramer, The Art of Improvisation, in The Masterwork in Music 1, William Drabkin ed. Cambridge: Cambridge University Press, 1994, p. 2-19 - which in turn draws extensively on Bach's chapter under consideration here. See also RINK. John. Schenker and Improvisation. Journal of Music Theory 1993, vol. 37, no. 1, p. 1-54. In contrast with the Schenkerian interest in elite experts, the current considerations reveal conventional aspects of Bach's compositions and treatise. 
CAPLIN, William E. Classical form: A Theory of Formal Functions for the Instrumental Music of Haydn, Mozart, and Beethoven. NY: Oxford University Press, 1998.

CHRISTENSEN, Thomas, The 'Règle de l'octave' in Thorough-Bass Theory and Practice," Acta Musicologica 1992, vol. 64, p. 91-117.

GJERDINGEN, Robert O. A Classic Turn of Phrase: Music and the Psychology of Convention. Philadelphia: University of Pennsylvania Press, 1988.

GJERDINGEN, Robert O. Music in the Galant Style. NY: Oxford University Press, 2007.

KRAMER, Richard. Unfinished Music. NY: Oxford University Press, 2008.

LESTER, Joel. Compositional Theory in the Eighteenth Century. Cambridge: Harvard University Press, 1992.

MEYER, Leonard B. Style and Music: Theory, History, and Ideology. Chicago: University of Chicago Press, 1989.

RIEPEL, Joseph. Anfangsgründe zur musicalischen Setzkunst (1. Band - De Rhythmopoeïa oder von der Tactordnung). Regensburg: Bader, 1752.

RINK. John. Schenker and Improvisation. Journal of Music Theory 1993, vol. 37, no. 1, p. 1-54.

SÁNCHEZ-KISIELEWSKA, Olga. Claves para el Análisis del Italianismo en la Música Hispana: Esquemas Galantes y Figuras Retóricas en las Misas de Jerusalem y Nebra. Diagonal: An IberoAmerican Music Review 2015 vol. 1, no. 1, p. 28-53.

SANGUINETTI, Giorgio. The Art of Partimento: History, Theory, and Practice. NY: Oxford University Press, 2012.

SCHANK, Roger-ABELSON, Robert. Scripts, Plans, Goals, and Understanding: An Inquiry into Homan Knowledge Structures. New York: Halsted, 1977.

SCHENKER, Heinrich. Ein Beitrag zur Ornamentik (Vienna: Universal, 1904/1907); trans. Hedi Siegel, A Contribution to the Study of Ornamentation, Music Forum 1976, vol. 4, p. 1-139.

SCHENKER, Heinrich. Die Kunst der Improvisation, in Das Meisterwerk in der Musik 1. Munich: Drei Masken Verlag, 1925, p. 11-40. Trans. Richard Kramer, The Art of Improvisation, in The Masterwork in Music 1, William Drabkin ed. Cambridge: Cambridge University Press, 1994, p. 2-19.

SCHULENBERG, David. The Music of Carl Philipp Emanuel Bach. Rochester, NY: University of Rochester Press, 2014. 